\title{
Respiratory Primordium
}

National Cancer Institute

\section{Source}

National Cancer Institute. Respiratory Primordium. NCI Thesaurus. Code C34283.

The laryng otracheal groove that extends lengthwise in the floor of the foregut just

caudal to the pharyngeal pouches, and that appears during approximately the fourth week of gestation. 